\title{
The Perception and Awareness Levels of University Students in Turkey Regarding Crisis Situations in Social Media: The University of Marmara Example
}

\author{
By Murat Seyfi* \\ Deniz Güven ${ }^{\dagger}$
}

Social media has brought to light new intended purposes by renewing itself in the new life space it created in the course of time. Especially, with the tendencies of universities, governments, non-governmental organizations and individual users, it was observed that social media was used very often in situations of political crises and natural disasters. In this study, a perception and awareness research has been made regarding how the youth in Turkey use social media in situations of crisis. At the end of the study, the perceptions of crisis were determined within the context of the sociocultural features of the youth, such as gender, life spaces and Internet usage habits.

Keywords: crisis, perception of crisis, social media

\section{Introduction}

With developments in communication technologies, the new media began taking up more space within communal living every passing day. At the same time, the new media affects the social relations of people, the social balance, the internal dynamics of the society and the life style of people. In a world where tools are the message itself, people are now developing new habits and creating new social life styles. The effect of the New Media in social life has multi-dimensional symmetrical interactions, rather than only one-dimension. For this reason, the new media, the individuals, society and cultural means affect each other and develop new channels to create a sustainable society within this process.

Today disasters and crises, which have an important place within social balance, take place worldwide in different shapes and with different speed. These crises sometimes cause great losses of human life or economic losses. For this reason, governments and non-governmental organizations try to take many protective and preventive measures in this field. In this type of crisis situations, institutional efforts are not solely sufficient; therefore, the role and efficiency of people have also changed and improved, parallel to the developments in communication technologies. Through new media, people

\footnotetext{
* Assistant Professor, Department of Public Relations and Advertising, School of Applied Sciences University of Gaziosmanpaşa, Turkey.

${ }^{\dagger}$ Research Assistant, Department of Public Relations, Faculty of Communication, University of Marmara, Turkey.
} 
have started going through crises and reacting to crises much more rapidly. Accordingly, many researchers have conducted studies on the usage levels of new media in crisis situations and created maps of new media tools for these situations.

In this study the users' of socio-cultural structures, particularly demographic features, were taken into account and their awareness levels regarding the matter were determined. Thus constituting a groundwork for both comparative studies and academic and educational programs to be structured in this field.

\section{Literature Review}

People's ways of communication have changed in conjunction with the development of new media. In crisis situations, beyond being just a communication tool, the new media turns into a new source of information (Cameron, Power, Robinson, and Yin, 2012). Social media is widely used by private citizens collaboratively coping with a crisis. Studies show that social media is used for collecting and distributing information, communicating and answering help requests (Starbird and Palen, 2011). During the big fire which started in Southern California in 2007, thousands of people were left homeless and hundreds of thousands of plantations were destroyed. When social media activity at that time was examined, it is observed that public based information is produced and distributed intensely. This leads us to the questioning of the functionality of new media use in disaster situations (Sutton, Palen, and Shklovski, 2008). The use of social media in disaster and emergency situations can be divided into two categories. The first is the passive use of social media. In other words, the passive distribution or sharing of information by the user. The second is the active use of social media by the user. Here, active usage can be evaluated in four categories (Lindsay, 2011, p. 1):

- Using the new medium to conduct emergency communications and issue warnings.

- Using uploaded images in order to create damage estimates, among others.

- To receive victim requests of assistance.

- Observing user activities to establish situational awareness.

Here the concepts of Real and Visual Volunteers emerge. Online volunteering means volunteer activities that are completed, in whole or in part, via the Internet on a home, work, or public access computer, usually in support of or through a mission-based organization (non-profit, NGO, civil society, etc.). The initial impression is that online volunteers are never seen by their host organization; but in fact, the majority of online volunteers support organizations locally, and volunteer onsite at such organizations in addition to volunteering online. Online volunteering is also called; virtual volunteering, 
online mentoring and so on (Cravens, 2006). Twitter and Facebook are applicable for studying virtual volunteers because they are intensively used during crises and the communication of its users takes place publicly. Therefore, many studies focus on the use of social media in crises. While looking into the habits of social media users, it was discovered that there are the so-called "information brokers" (Hughes and Palen, 2009). For instance, in the tornado disaster in 2011, called "the Super Outbreak", more than 340 people died. Heavy damages on houses, streets and cars were reported. During this disaster Twitter activities were examined and behaviours of Real and Visual Volunteers were analysed. As a result, despite the points where both groups overlap, different behaviours and tendencies were determined (Reuter, Heger, and Pipek, 2013, pp. 780-788). Even though the content, form and location of the disasters vary, the new media is present everywhere within the story, whether active or passive. In a case study conducted in South Korea, the effects of the disaster situation created by the H1N1 virus, which endangers human life directly, and the BSE virus, which is a cow disease, were examined, via new media. In both emergency situations, society used the new media intensively; however there were differences in the creation and treatment of the stories. Differences were determined also in the sharing of the contents of events by the government, depending on the risk level of the story. For this reason, the authorities have an important role in the positive direction and solution of the disaster in the new media (Chung and Yun, 2013, pp. 148-158). The concept of security comes up here, in the usage of new media in crisis situations. Apart from well-intentioned information sharing by individuals, illintentioned usage can also occur. Especially terror groups can disseminate information via social media in order to pave the way for a second attack (Lindsay, 2011, p. 7). That is why the source of information in social media generally depends on conventional media tools. Particularly authorities making official declarations prefer basing their sources of information on conventional media tools (Quarantelli, 1996, p. 5). In a study on real time usage analyses of Twitter, the natural disaster situations which occurred in the Pukkelpop festival in Belgium in the year 2011 were examined. In the statistical research, it was seen that even though there were tweets reporting doomster dark clouds and bad weather conditions, this did not create a warning effect and the number of tweets increased quite slowly. Even videos and photographs regarding the disaster were not very effective. However, after announcements made by official institutions via the conventional media, there was a serious increase in the number of tweets. Here, we see that the perception of gossip and troll sharing in crisis situations has an effect on the awareness levels of people. For this reason, in crisis situations it is necessary that governments and related institutions get involved via communication channels to support the correct information (Teun Terspra, Vries, Stronkman, and Paradies, 2012).

Natural and political crises occur almost everywhere in the world now. Likewise, in Turkey in the year 2013, the demonstrations that began with protests against trees' being cut in the Gezi Park in Istanbul, turned into a giant social-political crisis throughout the country. All crises that occurred were 
shared with the rest of the world via Twitter and Facebook. In fact, the number of people who were sharing the events on social media was quite few in the beginning; however, upon increase in violent messages within the process, social media became the most important communication tool in an instant. Twitter usage in Turkey during demonstrations was discussed in detail by the Social Media and Political Participation Laboratory of the University of New York. According to the report published by the University, on Friday, May 31st between 16:00 and 00:00, 2 million tweets were sent regarding the demonstrations. Within hashtags, \#direngezipark1 was in first place with 950 thousand tweets, \#occupygezi followed with 170 thousand tweets and \#geziparki with 50 thousand tweets. The report showed that even after midnight 3 thousand tweets were sent every minute while 90 percent of them originated from Turkey. The report pointed out to the fact that these numbers occurred in spite of weak or blocked $3 \mathrm{G}$ Internet access in the locations where the demonstrations were made, also pointing out that the surrounding businesses removed their wireless modem passwords. Facebook, which has more than 30 million users in Turkey, was also intensely utilized. With this rapid flow of communication, different dynamics of social media emanated, sometimes spontaneously and sometimes artificially. The source of the shared images and messages began to be discussed; many troll accounts shared fake images and messages to increase the chaos and manipulate the masses. On the other hand, humour was unfailing. The message of Turkish humourist Metin Üstündağ, "You are very beautiful when you are pissed off, my Turkey", was retweeted more than 17 thousand times. Likewise, many humorous messages were shared and retweeted by thousands of people, such as these: "Pepper gas is good for your skin; Pepper gas is a bit unpleasant at first but you get used to it; Pepper gas will not affect a nation which checks the camping cylinder with a lighter". Being Turkey's first serious experience with social media during a crisis, the Gezi Park incident has become an important starting point for the society, politicians, media managers and employees to self-criticize ${ }^{1}$.

In crisis situations, popular social media tools such as Twitter and Facebook are not the only means used. Other social media tools with different features, such as microblogs, are also actively used, integrated with other social media tools. For this reason, in order to keep the issue from being only a popular line or hearsay and develop more effective communication channels, communication strategies should be developed according to the features of social media tools. Within this context, an automated system was developed in Australia to extract important information from microblogging media such as Twitter in regards to crises witnessed by users. For the development and application of this type of applications, both governments and the society must work in a more organized way.

\footnotetext{
${ }^{1}$ Aydemir, Ş. Retrieved from: http://goo.gl/8oeNWV. [Accessed: 25 December 2015]
} 


\section{Method}

\section{Sample}

This study was conducted on students in the University of Marmara. The target population for this research are students with different majors of study in Turkey. From this population, a total of 148 graduate and undergraduate students who were selected using convenience sampling willingly participated in the study. The participants' ages ranged from 18 to 25 years. The survey was applied to 148 subjects, the 113 valid surveys were analysed within the context of the study. 72 of the subjects were women $(63.71 \%), 41$ were men $(36.28 \%)$.

\section{Instrument}

The onducted literature review demonstrated that there is not a scale study which analyses validity and reliability of people's use of social media in crisis situations. For this reason, a question repository was created, which consists of 16 questions, by conducting a literature review under the consultancy of 2 specialists, who work in crisis services, and 2 academicians, who implement studies regarding social media. Afterwards, the number of research questions consisting of Likert questions was decreased to 8 in consequence of pretesting. Furthermore, questions which would reveal the demographic features of individuals were asked in order for the sample to be well understood and to be analysed sophisticatedly. Studies conducted by Vieweg, Hughes, Starbird, and Palen (2010), Sakaki, Okazaki, and Matsuo (2010), Leavitt and Clark (2014), Palen and Liu (2007), Norton (2013), Coombs and Holladay (2012), FearnBanks (2011), Briones, Kuch, Liu, and Jin (2011), Akbayır and Kuşay (2015) were considered in this study.

\section{Results}

\section{Sample Demographics}

This study was conducted on students in the University of Marmara between the ages of 18-25. Within the scope of the study, a 5 point Likert scale research survey consisting of questions that will determine demographic characteristics was prepared. When we look at the tools the subjects use to connect to the Internet, the ones who use their mobile phones constitute $74.34 \%$ (84 students), the ones who use tablets $1.77 \%$ ( 2 students), the ones who use their own PC $23.89 \%$ (27 students). The distribution of the subjects according to their purpose in using social media is as follows: to communicate with friends $34.51 \%$ (39 students), to be informed about events $6.19 \%$ (7 students), to make remarks $7.96 \%$ (9 students), to listen to and share video/music $6.19 \%$ (7 students), and to keep track of current issues $44.25 \%$ (50 students). Regarding the change in the behaviour of subjects in social media 
during crisis situations, the distribution of the answers were: I only followed (51 students), I shared posts about the crisis (18 students), and I shared my own opinions (44 students). Regarding the duration of social media usage of the subjects during crisis situations: the ones whose duration of usage increased constitute $52.21 \%$ (59 students), the ones whose duration of usage decreased $0.88 \%$ ( 1 student), and the ones who state that their usage remained the same $46.90 \%$ (53 students).

Table 1. Demographics of the Participants

\begin{tabular}{|c|c|c|}
\hline & Frequency & Percentage \\
\hline \multicolumn{3}{|l|}{ Gender } \\
\hline Woman & 72 & 63.71 \\
\hline Man & 41 & 36.28 \\
\hline \multicolumn{3}{|l|}{ Where do you live now? } \\
\hline I live with my family & 51 & 45.13 \\
\hline I stay in a dormitory & 32 & 28.32 \\
\hline I share a flat with friends & 30 & 26.55 \\
\hline \multicolumn{3}{|l|}{ From where do you connect to Internet? } \\
\hline I connect by mobile phone & 84 & 74.34 \\
\hline My own PC & 27 & 23.89 \\
\hline Public places (labs, libraries, etc.) & 2 & 1.77 \\
\hline \multicolumn{3}{|c|}{ What is your purpose to use social media? } \\
\hline To communicate with friends & 39 & 34.51 \\
\hline To be informed about events & 7 & 6.19 \\
\hline To make remarks & 9 & 7.96 \\
\hline To share video/music & 7 & 6.19 \\
\hline To keep track of current issues & 50 & 44.25 \\
\hline Others & 1 & 0.88 \\
\hline \multicolumn{3}{|c|}{ Which activities did you do in crisis situations? } \\
\hline I only followed & 51 & 45.13 \\
\hline I shared posts about the crisis & 18 & 15.92 \\
\hline I shared my own opinions & 44 & 38.93 \\
\hline \multicolumn{3}{|c|}{ How did you use your time in social media in times of crisis change? } \\
\hline My duration of use increased & 59 & 52.21 \\
\hline My duration of use decreased & 1 & 0.88 \\
\hline My duration of use remained the same & 53 & 46.90 \\
\hline
\end{tabular}

Source: Authors' calculations. 
Table 2. The Perceptions of Participants about Crisis in Social Media

\begin{tabular}{|c|c|c|c|c|c|c|c|}
\hline & I absolutely disagree & I disagree & I am indecisive & I agree & I absolutely agree & Mean & Standard Deviation \\
\hline Questions & $N$ & $N$ & $N$ & $N$ & $N$ & & \\
\hline $\begin{array}{l}\text { Q1: I need to receive training to be } \\
\text { able to use social media more actively. }\end{array}$ & 27 & 42 & 12 & 19 & 5 & 2.24 & 1.20 \\
\hline $\begin{array}{l}\text { Q2: I think that social media use } \\
\text { during situations of political crisis and } \\
\text { natural disasters is useful. }\end{array}$ & 10 & 8 & 15 & 37 & 43 & 3.84 & 1.25 \\
\hline $\begin{array}{l}\text { Q3: The relevant institutions in Turkey } \\
\text { (disaster management centres, political } \\
\text { parties, NGOs etc.) conduct sufficient } \\
\text { studies in this field. }\end{array}$ & 13 & 40 & 43 & 11 & 6 & 2.61 & 0.99 \\
\hline $\begin{array}{l}\text { Q4: Usage of social media among the } \\
\text { subjects during political crises. }\end{array}$ & 8 & 16 & 15 & 55 & 19 & 3.53 & 1.14 \\
\hline $\begin{array}{l}\text { Q5: I actively use social media during } \\
\text { natural disasters. }\end{array}$ & 7 & 13 & 18 & 58 & 17 & 3.57 & 1.07 \\
\hline $\begin{array}{l}\text { Q 6: I think that the public is informed } \\
\text { about the use of social media. }\end{array}$ & 49 & 39 & 10 & 9 & 6 & 1.97 & 1.15 \\
\hline $\begin{array}{l}\text { Q7: I think that I can be useful to } \\
\text { society by using social media during } \\
\text { crisis situations. }\end{array}$ & 6 & 9 & 18 & 55 & 25 & 3.74 & 1.05 \\
\hline $\begin{array}{l}\text { Q 8: In crisis situations universities } \\
\text { should organize events to increase the } \\
\text { awareness levels of students. }\end{array}$ & 7 & 6 & 7 & 47 & 46 & 4.05 & 1.11 \\
\hline
\end{tabular}

Source: Authors' calculations. 
The answers to the 8 questions determine the perceptions of participants about crisis in social media. According to this, the question "In Crisis Situations Universities Should Organize Events to Increase the Awareness Levels of Students", which is one of the most important factors and has the highest average (4.05). Other high-average expressions are: "I Think That Social Media Use During Situations of Political Crisis and Natural Disasters Is Useful" (3.84), "I Think That I Can Be Useful to Society By Using Social Media During Crisis Situations" (3.74) (Table 2).

Table 3. Average Values according to Demographic Attributes

\begin{tabular}{|l|c|c|c|c|c|c|c|c|}
\hline & Q1 & Q2 & Q3 & Q4 & Q5 & Q6 & Q7 & Q8 \\
\hline Woman & 2.23 & 3.80 & 2.55 & 3.66 & 3.62 & 1.90 & 3.76 & 4.11 \\
\hline Man & 2.26 & 3.90 & 2.73 & 3.31 & 3.48 & 2.09 & 3.70 & 3.95 \\
\hline $\begin{array}{l}\text { The ones who live with } \\
\text { their family }\end{array}$ & 2.39 & 3.60 & 2.70 & 3.29 & 3.37 & 2.07 & 3.72 & 3.78 \\
\hline I stay in a dormitory & 2.12 & 3.87 & 2.68 & 3.65 & 3.65 & 1.71 & 3.81 & 4.25 \\
\hline $\begin{array}{l}\text { I share a flat with } \\
\text { friends }\end{array}$ & 2.13 & 4.2 & 2.4 & 3.83 & 3.83 & 2.06 & 3.70 & 4.30 \\
\hline $\begin{array}{l}\text { I connect by mobile } \\
\text { phone }\end{array}$ & 2.28 & 3.75 & 2.57 & 3.5 & 3.51 & 2.03 & 3.67 & 4.03 \\
\hline By my own PC & 2.22 & 4.14 & 2.85 & 3.62 & 3.81 & 1.74 & 3.96 & 4.14 \\
\hline $\begin{array}{l}\text { To communicate with } \\
\text { friends }\end{array}$ & 2.51 & 4.05 & 2.79 & 3.23 & 3.33 & 2.05 & 3.69 & 3.92 \\
\hline $\begin{array}{l}\text { To be informed about } \\
\text { events }\end{array}$ & 2.14 & 3.28 & 2.85 & 3.85 & 3.71 & 1.57 & 3.71 & 3.71 \\
\hline To make remarks & 3.33 & 3.22 & 2.66 & 3.22 & 3.44 & 2.22 & 3.22 & 3.66 \\
\hline To share video/music & 1.71 & 4 & 2.57 & 3.42 & 3.71 & 1.42 & 3.85 & 4.85 \\
\hline $\begin{array}{l}\text { To keep track of } \\
\text { current issues }\end{array}$ & 1.97 & 3.87 & 2.45 & 3.79 & 3.75 & 2.04 & 3.87 & 4.14 \\
\hline I only followed & 2.17 & 3.43 & 2.72 & 2.90 & 3.17 & 2.11 & 3.41 & 3.80 \\
\hline I shared the posts & 2.55 & 4 & 2.33 & 3.83 & 3.61 & 2.05 & 4 & 4.27 \\
\hline $\begin{array}{l}\text { I shared my own } \\
\text { opinions }\end{array}$ & 2.20 & 4.25 & 2.61 & 4.15 & 4.02 & 1.77 & 4.02 & 4.25 \\
\hline $\begin{array}{l}\text { My duration of use } \\
\text { increased }\end{array}$ & 2.40 & 4.03 & 2.50 & 3.94 & 3.77 & 2.05 & 4.03 & 4.08 \\
\hline $\begin{array}{l}\text { My duration of use } \\
\text { remained the same }\end{array}$ & 2.09 & 3.66 & 2.73 & 3.11 & 3.35 & 1.90 & 3.43 & 4 \\
\hline Soure: Ans & & & & & & & \\
\hline
\end{tabular}

Source: Authors' calculations.

Table 3 shows that there is not a huge difference in the mean values in terms of gender. Individuals who live with their friends attach more importance to the use of social media in crisis situations than individuals who live with their parents. In addition, the majority of the participants connect to the internet via their cell phones. Thus, they are always online. When compared to the others, internet usage time of those who use social media actively in crisis situations is increasing. Those who share their opinions through social media in 
crisis situations make up the group of people who mostly think that they have awareness about social media. Individuals who think that they can do beneficial things in crisis situations via social media have the highest average points in use of social media (4.03). Individuals who want to watch/listen movies and music over the internet make up the highest average in universities and similar institutions' increasing the awareness levels of the students in crisis situations (4.85).

\section{Conclusion}

With globalization and developments in communication technologies, the New Media began to be more efficient within social life each passing day. The New Media has become an important communication tool in the integration or disintegration of the society in crisis situations, or the fulfilling of urgent needs of individuals.

The questions prepared within the context of the study were written by researchers to examine the awareness levels of young people regarding the matter and to determine their needs, and were applied in the University of Marmara.

University student's being the most effected ones in Turkey from developments and innovations due to reasons such as literacy, knowing a foreign language, having a lot of free time, free thought environment, skills in social relations and age, and study's being conducted in one of the best universities in Turkey demonstrated that a major part of the participants are active in social media.

A major part of the participants who took part in the research use social media to communicate with their friends and to follow the agenda. This both demonstrates that the educated in Turkey develop their social relationships on online platforms and/or transfer their relationships to online platforms and explains the fact that the habit of reading the newspaper among the youth is declining day by day. Social media is becoming a growing platform each passing day on which people share both personal and social events and comment on them. A major part of the participants who took part in the research stated that they connect to the internet via their cell phones. Therefore, they have the ability to be online almost all the time and to react to crises immediately. Today, people's joining social media via cell phones and becoming active, make the questions that examine the time spent on social media meaningless. Mobile phone's being connected to the internet for 24 hours create a new passive-active state due to the fact that they continue to receive social media posts, although their users are not active for 24 hours. A major part of the participants who took part in the research stated that their spent time on social media and their sharing are increased in crisis situations. Moreover, participants state that the use of social media in crisis situations is beneficial, and it could do beneficial things for society by using social media in crisis situations. 
There are also vital relationships between the use of social media in crisis situations and demographic features. While there is a significant relationship between actual behaviours (sharing thoughts, sharing posts etc.) of participants in crisis situations and their level of awareness regarding the topic, there is not a serious difference in terms of gender. On the other hand, it is seen that socialisation is intense among the youth who share a flat with friends when awareness levels regarding Life Space are observed. This result could be associated with the conservative family structure in Turkey. University students have the highest levels of questioning in Turkey, and in situations in which their relationship with their family is restricted and they move away from their family they use social media more actively.

Questions 4 and 5 within this research demonstrated that participants do not differentiate political crises from natural disasters and perceive them both as crisis. This might be derived from socio-cultural features. The Turkish society thinks that the destructive effects of frequent natural disasters stem from false structuring, lawlessness, lack of inspection, income economy and false environmental policies, and thus they relate every natural disaster with government policies. (The Gezi Park protests in 2013 began with a few trees' being cut. In the earthquake in Marmara in 1999 whose intensity was 7,6 more than 17.000 people died, tens of thousands of people were wounded and hundreds of buildings were damaged according to official figures.) With a research, comparison of the youth in different countries will add a new dimension to the topic, since definite borders about the topic are not determined in the literature review. While some researchers relate the concept of crisis with natural disasters, others consider political crises and protests in this concept.

Individuals who took part in the research stated that they do not need any education about the use of social media while stating that the society is unconscious about this topic and they need to receive education in this area. It can be said that the youth are faced with the Dunning-Kruger effect (Savaş, 2016).

In literature researches about the topic (Yin, Karimi, Robinson, and Cameron 2012; Olteanu, Vieweg, and Castillo 2015; Cameron et al. 2012; Imran, Elbassuoni, Castillo, Diaz, and Meier 2013; Chung and Yun, 2013), it can be seen that the focus is generally on the analysis of huge data. Studies intended to analyse perceptions and awareness levels of people from the perspective of socio-cultural characteristics are scarcely any. Furthermore, social media is an important sharing platform for intercultural interaction. It is predicted that further studies about perceptions, awareness levels and behaviours of people in crisis situations, which are experienced by people from different nations simultaneously, and in which the effects of intercultural communication are observed will add a vital dimension to the topic. 


\section{References}

Akbayir, Z., \& Kuşay, Y. (2015). A Glance at Crisis from Social Media: A Research on Auto-motive Sector about Use of Social Media in Crisis.International Journal of Social Sciences and Education Research, 1(3), 1177-1193.

Briones, R.L., Kuch, B., Liu, B.F. and Jin, Y. (2011), "Keeping up with the digital age: how the American Red Cross uses social media to build relationships", Public Relations Review, Vol. 37 No. 1, pp. 37-43.

Cameron, M.A., Power, R., Robinson B. \& Yin, J. 2012. Emergency Situation Awareness from Twitter for Crisis Management, www 2012 Companion Conference, Lyon France

Chung J.B.\&Yun G.W. 2013. Media and Social Amplification of Risk:BSE and H1N1 cases in South Korea, Journal of Disaster Prevention and Management, Vol.22 No. 2

Coombs, W.T. and Holladay, J. (2012), "The paracrisis: the challenges created by publicly managing crisis prevention", Public Relations Review, Vol. 38 No. 3, pp. 408-415.

Cravens, J. (2006). Agency surveys 1997- 2000 in "Virtual Volunteering Project: Message and Survey Archive." www.serviceleader.org/old/vv/admin/, The Virtual Volunteering Project, University of Texas at Austin.

Fearn-Banks, K. (2011), Crisis Communications, 4th ed., Routledge, New York, NY.

Hughes, A. L., \& Palen, L. (2009). Twitter Adoption and Use in Mass Convergence and Emergency Events. In J. Landgren \& S. Jul (Eds.), Proc. ISCRAM. Gothenburg.

Imran, M., Elbassuoni, S. M., Castillo, C., Diaz, F., \& Meier, P. (2013). Extracting information nuggets from disaster-related messages in social media.Proc. of ISCRAM, Baden-Baden, Germany.

Leavitt, A., and Clark, J. A. Upvoting hurricane Sandy:event-based news production processes on a social news site. In Proc. of CHI (2014).

Lindsay, B.R. 2011. Social Media and Disaster: Current Uses, Future Options, and Policy Considerations, CRS Report.

Norton, C. (2013). Online crisis management. In R. Brown \& S. Waddington (Eds.), Share this too: More social media solutions for PR professionals (pp. 159-168). Cornwall, UK: John Wiley \& Son, Ltd.

Olteanu, A., Vieweg, S., \& Castillo, C. (2015, February). What to expect when the unexpected happens: Social media communications across crises. InProceedings of the 18th ACM Conference on Computer Supported Cooperative Work \& Social Computing (pp. 994-1009). ACM

Palen, L., and Liu, S. B. Citizen communications in crisis: anticipating a future of ICT-supported public participation. In Proc. of CHI (2007).

Quarantelli, E.L. 1996. Local Mass Media Operations in Disasters in the USA, Journal of Prevention and Management Vol.5 Number.5, 1996

Reuter, C., Heger, O., Pipek, V. 2013. Combining Real and Virtual Volunteers through Social Media, Proceeding of the 10 th International ISCRAM Conference, Germany

Sakaki, T., M. Okazaki, M. and Y. Matsuo. Earthquake shakes Twitter users: Realtime event detection by social sensors. In WWW, pages 851-860, Raleigh, NC,USA, 2010.

Savaş, S. (2016). Dunning-Kruger Sendromu ve Kurumsal Dışavurum. Akademia, 4/3, 2-16. doi: 10.17680/akademia.92350 
Starbird, K., \& Palen, L. (2011). Voluntweeters: Self-Organizing by Digital Volunteers in Times of Crisis. In Proc. CHI. Vancouver, BC, Canada: ACM Press

Sutton, J., Palen L.\&IShklovski, I. 2008. Backchannels on the Front Lines: Emergent Uses of Social Media in the 2007 Southern California Wildfires, Proceeding of the 5th International ISCRAM Conference, Washington, USA

Teun Terspra, T., Vries, A.D., Stronkman, R.6 \& Paradies, G.L. 2012. Towards a Realtime Twitter Analysis During Crises For operations Crisis Management, Proceeding of the 10 th International ISCRAM Conference, Vancouver, Canada

Vieweg, S., Hughes, A.L., Starbird, K. and Palen,L. Microblogging during two natural hazards events: What Twitter may contribute to situational awareness. In HCI, pages 1079-1088, Atlanta, GA, USA, 2010.

Yin, J., Karimi, S., Robinson, B., Cameron, M., 2012. ESA:Emergency Situation Awareness via Microbloggers, Proceedings of the 21st ACM international conference on Information and knowledge management, ACM Publications, doi: $10.1145 / 2396761.2398732$ 